\title{
Normative Rapprochement and Security Cooperation Between China and the European Union
}

\author{
Marlene Kramer, Maastricht University
}

\section{Introduction}

In the last half century, the world has shifted from a bipolar, to a unipolar, and now a multipolar order. ${ }^{1}$ The post-Cold War era has been characterized by profound and complex changes, leading to the rise of non-traditional security threats that require new responses and enhanced cooperation between international security actors. ${ }^{2}$ Today, two of the most important actors are the People's Republic of China and the European Union. The European Union emerged as a key international security actor in the 1990s with the establishment of the Common Foreign and Security Policy (CFSP) in 1992, and the European Security and Defense Policy (ESDP) in 1999, which was later revised into the Common Security and Defense Policy (CSDP) within the 2009 Lisbon Treaty. On the other hand, in conjunction with its rising economic might, China has developed into a key global actor within the last decade by expanding its participation in peacekeeping operations, conducting more multilateral exercises beyond East Asia, and investing heavily in military projection through the construction of overseas bases. ${ }^{3}$

[1] Marlene Kramer is German and French. She received her Bachelor's degree in Political Science and International Relations at the University of Aberdeen in Scotland. She completed her Master's degree at Maastricht University in the Netherlands in the European Studies Program, where she specialized in International Relations and conducted this research on EU-China relations. She developed her interest in this area during an exchange semester at Hong Kong University.

[2] Mary Kaldor, Mary Martin, and Sabine Selchow, "Human Security: A New Strategic Narrative for Europe," International Affairs 83.2 (2007): 279, https://doi.org/10.1111/ j.1468-2346.2007.00618.x

[3] See Zhu Liqun, "China’s Foreign Policy Debates," Chaillot Papers 121 (2010): 38- 
Since the PRC and the EU first established formal diplomatic ties in 1975, economic and political globalization have pushed the two powers closer. Economic and political aspects of the EU-China relationship remain dominant pillars in the relationship, but international security issues have come to the forefront in recent years. ${ }^{4}$ Bilateral and multilateral agreements, such as the 2003 EU-China Comprehensive Strategic Partnership and the EU-China 2020 Strategic Agenda for Cooperation, have institutionalized security cooperation between China and the EU. In particular, the 2003 Strategic Partnership marks a crucial turning point in EU-China relations, and is of particular importance for the study of security cooperation. As the document states, one of its main objectives is the "deepening and broadening [of] cooperation and enhancing bilateral collaboration on a wide range of policy areas at the global level."5 Such enhanced cooperation implicates key domains of international security like the fight against terrorism and nuclear non-proliferation.

However, despite its newfound importance, EU-China security relations have received limited scholarly attention thus far. To this point, studies of EU-China relations have primarily focused on economic factors, such as trade and economic development, and have largely sought to highlight systemic differences between the two powers, while framing their relationship as fundamentally competitive. ${ }^{6}$ But this is

40, https://doi.org/10.2815/19538; Mikko Huotari, Jan Gaspers, and Thomas Eder et al., "China's Emergence as a Global Security Actor: Strategies for Europe," report, Mercator Institute for China Studies, in MERICS Papers on China 4 (June 2017): 15, https:// merics.org/en/report/chinas-emergence-global-security-actor; Sven Biscop and Liselotte Odgaard, "The EU and China: Partners in Effective Multilateralism," in The International Politics of EU-China Relations, ed. David Kerr and Liu Fei (Oxford University Press, 2006): 1, https://doi.org/10.5871/bacad/9780197264089.001.0001

[4] Emil Kirchner, Thomas Christiansen, and Han Dorussen, "EU-China Security Cooperation in Context," in Security Relations Between China and the European Union, ed. Emil Kirchner, Thomas Christiansen, and Hans Dorussen (Cambridge, GBR: Cambridge University Press, 2016): 1.

[5] Jing Men and Ramon P. Pardo, "Convergence and Divergence Between the EU and China," Asia Europe Journal 12.1-3 (2014): 1-3, https://doi.org/10.1007/s10308-014-0377-7 [6] See Richard Maher, "The Elusive EU-China Strategic Partnership," International Affairs 92.4 (2016): 959-976, https://doi.org/10.1111/1468-2346.12659; Ramon P. Pardo, a mistake-as $\mathrm{Xu}$ argues, examining the root causes and cascading effects of EU-China cooperation in the realm of international security is important for several reasons. ${ }^{7}$ First, cooperation could lead to greater international stability in an increasingly complex and uncertain global order. Second, mutual cooperation benefits both powers by increasing their influence and insulating them from other threats and rivals. Third, increasing security cooperation could relieve tensions between the two powers and bolster cooperation across other areas, such as trade and economic development. Fourth, cooperation could prevent the deleterious effects of security competition between the EU and China. As $\mathrm{Xu}$ asserts, EU-China cooperation in international security "is not only an effort towards a better relationship, but also a necessary insurance against negative developments."

To fully understand the nature of China-EU security cooperation, we need to examine the ways in which the two powers understand each other's goals and interests in the realm of international security. In other words, we must understand the extent to which Chinese and European norms on international security have converged over the past decades. ${ }^{9}$ Through a macro-analysis of key Chinese and European policy documents, I argue that since the signing of the 2003 Strategic Partnership, China and the European Union have experienced a moderate level of normative convergence. This convergence has occurred primarily due to three main factors: first, the EU and China have developed shared

"EU-China Relations in Financial Governance: Cooperation, Convergence or Competition?" Asia Europe Journal 12.1 (2014): 63-77, https://doi.org/10.1007/s10308-014-0372-z; Liu Lei, Wu Tong, and Wan Ziqianhong, "The EU-China relationship In a New Era of Global Climate Governance," Asia Europe Journal 17.2 (2019): 243-254, https://doi. org/10.1007/s10308-018-00530-2

[7] See Xu Qiyu, "Managing Uncertainties: China-EU International Security Cooperation," occasional paper, Institute for Security and Development Policy, in Asia Papers Series (September 2009): 14-17, https://www.isdp.eu/content/uploads/publications/2009_ qiyu_managing-uncertainties.pdf

[8] Ibid., 15.

[9] See Gustaaf Geeraerts, “The EU-China Partnership: Balancing Between Divergence and Convergence," Asia Europe Journal 17.3 (2019): 282-283, https://doi.org/10.1007/ s10308-019-00554-2 
threat perceptions, particularly in regard to non-traditional security threats; second, both powers have recognized the effectiveness of multilateral action through the United Nations and other international organizations; and third, Chinese understanding of sovereignty and non-interference has become more flexible in response to pragmatic considerations.

In this paper, I will first review current academic approaches towards international security cooperation between China and the EU and detail the historical background of EU-China security cooperation and each power's respective approach towards security issues. I will then apply a constructivist framework of normative rapprochement towards a discursive analysis of post-2003 policy documents from both China and the EU, as well as case studies of international peacekeeping missions on the African continent. This research will not only further the academic debate on normative rapprochement, but also add to the literature on China vis-à-vis Western perceptions and international power structures.

\section{The EU as an International Security Actor}

The changing post-Cold War landscape has emboldened the European Union's global security ambitions. Under the auspices of the CFSP, CSDP, and the 2003 European Security Strategy (ESS), the EU has begun to play a more active role in international security by engaging in several military and civilian CSDP operations across the world. ${ }^{10}$ In 2003, the EU launched its first coordinated peacekeeping operation, Concordia, in the former Yugoslav Republic of Macedonia, and has since then undertaken several similar missions on three continents. ${ }^{11}$ As the ESS proclaims, "in a world of global threats, global markets and global media, our security and prosperity increasingly depend on an effective multilateral system." ${ }^{12}$ The ESS highlights the EU's commitment

[10] See Sonia Lucarelli, Luk Van Langenhove, and Jan Wouters, The EU and Multilateral Security Governance (Abingdon, GBR: Routledge, 2013).

[11] Trineke Palm and Ben Crum, "Military Operations and the EU's Identity As an International Security Actor," European Security 28.4 (2019): 513, https://doi.org/10.1080/ 09662839.2019.1667769

[12] "A Secure Europe in a Better World," document, Council of the European Union to multilateralism and cooperation, and has set the tone for the EU's conduct in foreign and security policy in recent decades. As noted by a 2008 follow-up report on the implementation of the ESS, though the EU is still adapting its role in international security, it has made substantial progress since 2003, and is "recognized as an important contributor to a better world." ${ }^{13}$

The EU's increasingly prominent international role has also become a subject of academic debate. Palm and Crum identify three main academic stances toward the EU's security role: Normative Power, Realist Power and Liberal Power. ${ }^{14}$ In particular, the concept of Normative Power Europe (NPE) by Manners and the concept of civilian power by Duchêne have received significant attention. Manners' concept of NPE and its social-constructivist approach is based on the assumption of a distinctive EU identity and focuses on the importance of values, principles, and norms for understanding the EU's international behavior. ${ }^{15}$ NPE details the idea that the EU has the "ability to shape conceptions of 'normal' and can thus promote and defend universal values. ${ }^{16}$ On the other hand, Duchêne's conception of civilian power envisions a Europe that advances its agenda through non-military means like trade and diplomacy. ${ }^{17}$

Despite the prevalence of the NPE concept in academic discourse, realist and liberal scholars have offered alternative perspectives on the

(December 2003): 9, https://data.consilium.europa.eu/doc/document/ST-15895-2003INIT/en/pdf

[13] "Report on the Implementation of the European Security Strategy: Providing Security in a Changing World," report, European Union (2008): 2, https://www.consilium. europa.eu/uedocs/cms_data/docs/pressdata/en/reports/104630.pdf

[14] Palm and Crum, "Military Operations and the EU's Identity," 517.

[15] See Kamil Zwolski, "The EU and a Holistic Security Approach after Lisbon: Competing Norms and the Power of the Dominant Discourse," Journal of European Public Policy 19.7 (2012): 988-1005, https://doi.org/10.1080/13501763.2012.662057

[16] Manners, "Normative Power Europe," 239.

[17] See Francois Duchêne, "Europe's Role in the World," in Europe Tomorrow, ed. Richard Mayne (Glasgow, GBR: Fontana, 1972): 32-47; Ian Manners, "Normative Power Europe: A Contradiction in Terms?" Journal of Common Market Studies 40.2 (2002): 235-258, https://doi.org/10.1111/1468-5965.00353 
EU's security identity. Realist scholars question the distinctiveness of the EU' security identity, and stress the interest-driven nature of EU foreign policy as opposed to the values-based position described in Manners' work..$^{18}$ Liberal scholars, on the other hand, recognize the distinctiveness of the EU, but argues that this is due to economic factors-particularly, its single market-as opposed to EU-specific norms and principles. ${ }^{19}$

While I acknowledge the relevance of diverging views of the EU's identity as a global actor, for the purpose of this research, we will utilize a norms-based approach, as it more accurately reflects the EU's self-identification as a normative global power. ${ }^{20}$ Normative promotion on an international scale is central to the EU's foreign policy, considering its aim for international security through the promulgation of European norms. The EU's self-prescribed role as a normative power and aspirations to be a global actor are reflected in the ESS, which advances two main normative principles: effective multilateralism and a rule-based international order in an increasingly multipolar and complex world. ${ }^{21}$ As Palm and Crum have noted, most overseas EU military operations were not initiated to fulfil geostrategic or economic objectives, but rather, were initiated in accordance with normative principles. ${ }^{22}$ In other words, the international security actions taken by the EU reflect its discursive conceptualization as a normative power.

\section{China as an International Security Actor}

China's approach to international security issues has evolved over time. During the Cold War, the Chinese government largely focused on domestic issues, such as safeguarding national sovereignty and territorial integrity. However, following 1970 s economic reforms and the economic boom in subsequent decades, China has adopted a wider outlook towards international security, becoming a key actor within the new mul-

[18] Palm and Crum, "Military Operations and the EU's Identity," 517.

[19] See Chad Damro, "Market Power Europe," Journal of European Public Policy 19.5 (2012): 682-699, https://doi.org/10.1080/13501763.2011.646779

[20] Palm and Crum, "Military Operations and the EU's Identity," 513.

[21] See "A Secure Europe in a Better World."

[22] Palm and Crum, "Military Operations and the EU's Identity," 534. tipolar global order. ${ }^{23}$ Initially, China has focused on regional issues and multilateralism through cooperative organizations, including the Asia-Pacific Economic Cooperation (APEC) and the Shanghai Cooperation Organization (SCO). ${ }^{24}$ But in recent years, China has sought to further internationalize its approach to security. Over time, China has reconstructed its identity as a peaceful and cooperative global actor, shifting from a 'norm taker' to a 'norm maker. ${ }^{25}$

The 2003 Chinese New Security Concept (NSC) illustrates China's changing international security policy, emphasizing mutually beneficial cooperation, rather than self-determination and national sovereignty. The core components of China's 2003 NSC are mutual trust, mutual benefit, equality, and coordination. ${ }^{26}$ This new approach complements China's overall foreign policy of peaceful ascent and peaceful development. For instance, the NSC closely parallels the Five Principles of Peaceful Coexistence, which can be understood as key Chinese foreign policy norms: "mutual respect for sovereignty and territorial integrity, mutual non-aggression, non-interference in each-others internal affairs, equality and mutual benefit, and peaceful coexistence." ${ }^{27}$ These concepts serve to counter growing international skepticism of China's rise, as it

[23] See Song Xinning, "Security and the Role of China," in The Palgrave Handbook of EU-Asia Relations, ed. Thomas Christiansen, Emil Kirchner, and Philomena Murray (London, GBR: Palgrave Macmillan, 2013); Chu Shulong, "China’s Perception and Policy About North Korea," American Foreign Policy Interests 37.5-6 (2015): 273-278, https:// doi.org/10.1080/10803920.2015.1162065; Jörn-Carsten Gottwald and Niall Duggan, "Hesitant Adaptation: China's New Role in Global Policies," in Role Theory in International Relations, ed. Sebastian Harnisch, Cornelia Frank, and Hanns W. Maull (London, GBR: Routledge, 2011).

[24] Song, "Security and the Role of China," 472.

[25] See Reuben Wong, "China's Security Thinking," policy paper, EU-China Security Cooperation, University of Essex, in EUSC Policy Paper Series (2015): 2-4, https://www. essex.ac.uk/-/media/documents/research/eu-china/eusc_security_china_wong.pdf; Chris Alden and Daniel Large, "On Becoming a Norms Maker: Chinese Foreign Policy, Norms Evaluation and the Challenges of Security in Africa," The China Quarterly 221 (2015): 123-142, https://doi.org/10.1017/S0305741015000028

[26] Alden and Large, "On Becoming a Norms Maker," 474.

[27] Liu Guoli, "Leadership Transition and Chinese Foreign Policy," Journal of Chinese Political Science 8.1 (2003): 107, https://doi.org/10.1007/BF02876952 
emphasizes that the Chinese government does not aim to threaten the existing international order but instead, are helping to maintain a harmonious and cooperative global environment. ${ }^{28}$ This evolution of Chinese foreign policy has also had practical implications, as the country has become more supportive of international intervention. For instance, China has become increasingly active in UN peacekeeping missions abroad, and is now one of the leading contributors of peacekeeping personnel. ${ }^{29}$

\section{Debates on EU-China Security Cooperation}

We will now engage with the academic debate on EU-China rapprochement on global security issues to provide further insights on the practical implications of cooperation between the two powers. While some scholars doubt the potential for cooperation between major powers, others have argued-based on official statements and policy papersthat cooperation between the EU and China is both deepening and widening..$^{30}$ Realist scholars tend to disregard the prospects of such cooperation between key international players, and instead, focus on theories of competition and great power rivalry. The realist school identifies the rising importance and assertiveness of China as a threat to the existing international system, rather than an opportunity for global stability. ${ }^{31}$

However, many scholars foresee potential benefits of EU-China cooperation, noting various factors that could impact the likelihood of cooperation: including the role of the US, the ongoing EU arms embargo

[28] Peer M. Christensen and Li Xing, "China’s Self-Perception of Its Security Situation: The Nexus of the Internalities and Externalities," Journal of China and International Relations 1.1 (2013): 32, https://doi.org/10.5278/ojs.jcir.vli1.215

[29] Miwa Hirono and Marc Lanteigne, "Introduction: China and UN Peacekeeping," International Peacekeeping 18.3 (2011): 245-246, https://doi.org/10.1080/13533312.2011.5 63070

[30] See Jing and Pardo, "Convergence and Divergence between the EU and China," 1-3; David Scott, "Environmental Issues as a 'Strategic' Key in EU-China Relations," Asia Europe Journal 7 (2009): 211-223, https://doi.org/10.1007/s10308-009-0227-1

[31] See Graham Allison, Destined for War: Can America and China Escape the Thucydides Trap? (Boston, MA: Houghton Mifflin, 2017); Abramo F.K. Organski, World Politics (New York, NY: Alfred A. Knopf, 1958). on China, national interests, and certain normative factors. ${ }^{32}$ Geeraerts, for instance, notes the mixed nature of EU-China relations, arguing that although certain factors indicate that competition exists between the two powers, others indicate converging trends that denote prospects of cooperation. ${ }^{33} \mathrm{He}$ further argues that competition and cooperation are compatible, as power relations and conflicts of interest explain the competitive nature of the relationship, but shared rules and norms serve to undergird bilateral cooperation.

This correlation between normative convergence and levels of cooperation has been established by other authors as well. Finamore hypothesizes that, based on social constructivist theory, normative differences could explain a lack of cooperation between different powers. ${ }^{34}$ Accordingly, for concrete security cooperation, "a convergence of interests is not enough; there is also a need for a convergence of ideas about security and the way to provide it." ${ }^{35}$ Other authors have analyzed prospects of EU-China security cooperation by focusing on the role of norms and interests, and the potential impact of normative convergence on de facto cooperation. Most argue that Chinese and European norms are in fact diverging, or that there is only a limited rapprochement of norms and conceptual understandings. ${ }^{36}$ For example, Stumbaum finds that

[32] See Emil Kirchner, Thomas Christiansen and Han Dorussen, Security Relations Between China and the European Union: From Convergence to Cooperation? (Cambridge, GBR: Cambridge University Press: 2016): 1-18; Simone Dossi, "The EU, China and Nontraditional Security: Prospects for Cooperation in the Mediterranean Region," Mediterranean Quarterly 26.1 (2015): 77-96, https://doi.org/10.1215/10474552-2872988; Salvatore Finamore, "Normative Differences in Chinese and European Discourses on Global Security: Obstacles and Opportunities for Cooperation," Chinese Political Science Review 2 (2017): 159-178, https://doi.org/10.1007/s41111-017-0049-z

[33] See Gustaaf Geeraerts, “The EU-China Partnership,” 281-294.

[34] Finamore, "Normative Differences in Chinese and European Discourses on Global Security," 159-178.

[35] Dossi, "The EU, China and Nontraditional Security," 78.

[36] See Salvatore Finamore, "Normative Differences in Chinese and European Discourses on Global Security," 159-178; Francesco S. Montesano, "EU-China Security Relations: Discourse vs Practice and the Role of EU Member States," The International Spectator 54.2 (2019): 139-158, https://doi.org/10.1080/03932729.2019.1572356; Daniela Sicurelli, "Competing Models of Peacekeeping: The Role of the EU and China in Af- 
although the two powers' threat perceptions have aligned, they nonetheless have diverging connotations of core terms, such as multipolarity, and core concepts, such as human rights and democracy. ${ }^{37}$ While Stumbaum questions the probability of comprehensive EU-China security cooperation in the future, she identifies areas in which future cooperation is more likely to happen. These include areas of human security lime environmental disasters and pandemics, as well as humanitarian interventions like peacekeeping. ${ }^{38}$

In a similar fashion, Montesano highlights the discrepancy between official discourse and actions on the ground when it comes to EU-China security cooperation, arguing that "convergent perceptions have not translated into convergent responses" due to differing approaches to most security issues. ${ }^{39}$ Nevertheless, his analysis of European and Chinese peacekeeping has led him to claim a slowly evolving normative rapprochement, particularly due to recent Chinese pragmatic flexibility in its security approach. Montesano's finding of growing flexibility and potential for future normative rapprochement is strengthened by Kerr and Xu's research, which reveals not only the mobility of norms of security governance between China and the EU, but the gradually closing gap between them..$^{40}$ Similarly, Kirchner et al.s study of ten security dimensions found that while there is no high or uniform level of convergence across the different dimensions, the overall impression of low and medium levels still indicates a significant degree of positive normative

rica," conference paper, Fifth Pan-European Conference on EU Politics (Porto, PRT), ECPR Standing Group on the European Union, June 23-26, 2010, http://citeseerx.ist.psu. edu/viewdoc/download?doi=10.1.1.462.9906\&rep=repl\&type=pdf

[37] Montesano, "EU-China Security Relations," 139-158; Kirchner, Christiansen, and Dorussen, "Security Cooperation in EU-China Relations," 1-18; see May-Britt Stumbaum, "Opportunities and Limits of EU-China Security Cooperation," The International Spectator 42.3 (2007): 351-370, https://doi.org/10.1080/03932720701567570

[38] Stumbaum, "Opportunities and Limits of EU-China Security Cooperation," 351370; Xu, "Managing Uncertainties," 5-40.

[39] Montesano, "EU-China Security Relations," 143.

[40] David Kerr and Xu Yanzhuo, "Europe, China and Security Governance: Is There Evidence of Normative Convergence?" Asia Europe Journal 12 (2014): 79-93, https://doi. org/10.1007/s10308-014-0371-0 rapprochement. ${ }^{41}$ Finally, Xu also supports this line of argumentation, asserting that not only have the EU and China adopted similar threat perceptions, but that China "increasingly resembles the EU in terms of its security approach, providing a better groundwork for cooperation." ${ }^{32}$

However, it is important to note, as Kirchner et al. do, that generalizations on convergence and cooperation are difficult, and that analyses and conclusions need to be made on a case-by-case basis. ${ }^{43}$ The literature on EU-China security cooperation and normative rapprochement is still relatively new, with a limited amount of current research. Most scholars have focused on cases where levels of cooperation between the EU and China are expected to be high, such as anti-piracy cooperation in Somalia and joint action in relation to the Iran Nuclear Deal have been highlighted. ${ }^{44}$ Similarly, some authors have sought to study peacekeeping missions in African countries, such as Mali and Sudan..$^{45} \mathrm{Xu}$, for instance, has argued that EU-China security cooperation could be particularly significant in African peacekeeping missions. ${ }^{46}$

\section{Methodology: Analyzing Normative Convergence and Levels of Cooperation}

Norms and their convergence can have a tangible impact on facilitating international cooperation. ${ }^{47}$ In recent years, the concept of normative rapprochement has begun to spread in the literature on globalization

[41] See Kirchner, Christiansen and Dorussen, "Security Cooperation in EU-China Relations," 1-18.

[42] Xu, "Managing Uncertainties," 17.

[43] Kirchner, Christiansen and Dorussen, "Security Cooperation in EU-China Relations," 17.

[44] See Finamore, "Normative Differences in Chinese and European Discourses on Global Security," 159-178; Montesano, "EU-China Security Relations," 139-158; Dossi, "The EU, China and Nontraditional Security," 77-96; Kirchner, Christiansen and Dorussen, "Security Cooperation in EU-China Relations," 17.

[45] See Montesano, "EU-China Security Relations," 139-158; Kerr and Xu, "Europe, China and Security Governance," 79-93.

[46] See Xu, "Managing Uncertainties," 5-40.

[47] Finamore, "Normative Differences in Chinese and European Discourses on Global Security," 159-178; Daniel W. Drezner, "Globalization and Policy Convergence," International Studies Review 3.1 (2011): 53-78, https://doi.org/10.1111/1521-9488.00225 
and modernization. According to Kerr, normative rapprochement can be defined as "the tendency of societies to grow more alike, to develop similarities in structures, processes and performance."38 In order to investigate normative rapprochement between China and the EU, I will utilize a macro-level discursive analysis of official documents and statements to measure convergence or divergence between the two actors' attitudes and approaches. Several authors have demonstrated the importance of studying normative convergence and divergence in relation to international security cooperation. ${ }^{49}$ As previously noted, Kirchner et al., for instance, have established a link between normative rapprochement and security cooperation between the EU and China by testing it within ten different security dimensions. They find that there is often a "strong link between the existence of policy conformity and levels of cooperation," despite occasional discrepancies. However, it is worth noting that cooperation can occur independently of normative rapprochement in cases that require the spontaneous cooperation of key actors, such as responses to natural disasters or pandemic diseases..$^{\circ}$ Even though normative rapprochement is not the only factor affecting security cooperation between the EU and China, the correlation between the two factors makes it important to study. ${ }^{51}$

While some scholars in the field of EU-China security cooperation have drawn on such an approach to argue that differences related to issues such as sovereignty, human rights, and democracy between China and the EU have impacted their ability to reach agreements and act jointly, I argue that it is more important to study international actors' ability

[48] Clark Kerr, The Future of Industrial Societies: Convergence or Continuing Diversity? (Cambridge, MA: Harvard University Press, 1983): 3.

[49] Kirchner, Christiansen and Dorussen, "Security Cooperation in EU-China Relations," 78; Montesano, "EU-China Security Relations," 139-158; Finamore, "Normative Differences in Chinese and European Discourses on Global Security," 159-178.

[50] Kirchner, Christiansen and Dorussen, "Security Cooperation in EU-China Relations," 6.

[51] See Ai Weining and Song Weiqing, "China and the European Unions' Participation in Conflict Resolution: Norm Dynamics, Convergence and Divergence in Foreign Policy," Journal of Contemporary China 28.116 (2019): 277-292, https://doi.org/10.1080/106 70564.2018.1511397 to overcome normative differences in order to understand and promote opportunities for cooperation. ${ }^{52}$ For my purposes, I borrow Kirchner et al.s definition of normative convergence: "the degree of actual security cooperation between the EU and China, whether in the shape of formal agreements or of joint actions involving either material resources or firm commitments to joint standards." ${ }_{33}$

Having defined normative convergence, I will now elaborate on how I intend to measure it. Our categories of analysis are based on recurring themes in the academic literature on EU-China security cooperation, particularly Kirchner et al's, Montesano's, and Finamore's research. ${ }^{54}$ Normative convergence will be tested on two main axes: threat perception and policy responses. I will first explore threat perception by both the EU and China, measuring the extent to which they have converged since the formation of their strategic partnership in 2003. To analyze threat perception on the macro-level of normative convergence, I will examine what the EU and China perceive as threats, and how they justify these perceptions. I will then contrast EU and Chinese threat perception together to see if there is an observable normative convergence between the actors. Next, I will examine security norms surrounding Chinese and European policy responses to international security threats and measure the extent of that convergence as well. I will pay special attention to the two powers' respective understandings of key normative concepts, such as sovereignty, interventionism, multilateralism, and multipolarity. These norms have been identified by Finamore as particularly relevant to the EU-China security cooperation relationship. ${ }^{55}$ Finally, I will test the self-perceptions of the two powers and their relative perceptions of each other for convergence, as relative framings and self-perception can reveal actors' motivations, ambitions, and strategic

[52] Kirchner, Christiansen and Dorussen, "Security Cooperation in EU-China Relations," 6.

[53] Ibid.

[54] Ibid.; Montesano, "EU-China Security Relations," 139-158; Finamore, "Normative Differences in Chinese and European Discourses on Global Security," 159-178.

[55] See Finamore, "Normative Differences in Chinese and European Discourses on Global Security," 159-178. 
interests. Particular levels of convergence will be evaluated using Kirchner et al's categorization of convergence levels, as listed below:

High: Similar degrees of threat perception and high degree of overlap in relevant domestic response.

Medium: Either variation in the degree to which they perceive the level of threat in a particular issue domain or in how their domestic policies respond to these threats.

Low: Variation in the way they perceive the threat, and in the extent or degree to which domestic actions have been introduced..$^{5}$

This analysis will be conducted within a framework of qualitative, macro-level discursive analysis. A qualitative content analysis consists of an interpretative form of analysis that is primarily concerned with the examination of text itself to uncover meanings, motives and purposes in textual content. ${ }^{57}$ In other words, I will textually and thematically evaluate key European and Chinese documents from 2003 to 2019 that either illuminate each power's stance on global security and international cooperation, European-Chinese relations, or both. This time frame has been chosen since the EU-China strategic partnership was signed in 2003, which initiated China and the EU's shared commitment to increased cooperation on global security issues. Due to the limited number of official sources, our analysis will only include documents up to the year 2019. Afterwards, I will also include a short case study of Chinese and European peacekeeping in the Democratic Republic of Congo (DRC) to validate my conclusions in a real-world context.

\section{The EU's Approach to International Security and China}

\section{Documents}

I begin my analysis with the European Security Strategy (ESS) and a

[56] See Kirchner, Christiansen and Dorussen, "Security Cooperation in EU-China Relations," 1-18.

[57] Sandra Halperin and Oliver Heath, Political Research: Methods and Practical Skills (New York, NY: Oxford University Press, 2017): 336.
2003 European Commission policy paper on China, "A Maturing Partnership: Shared Interests and Challenges in EU-China Relations," as these two documents redefined the EU's policies towards China and global security for the following decade. The ESS is primarily oriented towards international policy and aims to reinforce the CFSP and provide a clear guide for the EU's role in global security affairs. The EU-China comprehensive strategic partnership, on the other hand, aimed to expand cooperation on global security issues, thereby moving the EU and China's relationship beyond a purely economic partnership. In terms of threat perception, both documents highlight the rapidly changing nature of international security threats-in sum, arguing that security threats are more diverse, less visible, and predictable. My analysis of both documents identifies five common international security threats: terrorism, proliferation of weapons of mass destruction, regional conflicts, state failure, and organized crime..$^{8}$ In terms of policy response, "A Maturing Partnership" has an idealistic and optimistic tone, stressing an ambition to strengthen their relationship through the elaboration of six priorities: shared responsibility in the promotion of global governance, supporting a Chinese transition based on the rule of law and respect for human rights, support for China's economic opening-up, raising the efficiency of inter-party political dialogue, and bettering their joint abilities to address international governance and global security. The paper calls for heightened cooperation to tackle increasingly global and interdependent security issues, and identifies China as a key partner in this goal.

On the other hand, the ESS states the importance of respecting states' sovereignty, independence and territorial integrity, peaceful settlement of disputes, and abiding by key UN principles and commitments. ${ }^{59}$ In addition, it clarifies that sovereignty entails responsibility, referring to a

[58] "A Secure Europe in a Better World"; "A Maturing Partnership-Shared Interests and Challenges in EU-China Relations," policy paper, Commission of the European Communities (2003), https://eur-lex.europa.eu/LexUriServ/LexUriServ. do?uri=COM:2003:0533:FIN:EN:PDF

[59] "A Maturing Partnership-Shared Interests and Challenges in EU-China Relations." 
global responsibility to protect populations from genocide, war crimes, ethnic cleansing, and crimes against humanity. Although the importance of supporting multilateralism-and especially the United Nations-is heavily emphasized in both documents, the ESS particularly emphasizes the importance of multilateral agreements and coordination through international organizations, as well as the importance of forming partnerships with other key players in international affairs. To that end, the ESS includes a section on partnerships for effective multilateralism, which not only identifies the existing network of cooperation between the United States and the EU, but also mentions progress made in strengthening cooperation with China. According to the ESS, the EU is meant to play an active role-in other words, it is Europe that must lead a renewal of the multilateral order.

Moreover, it is of particular importance that both documents introduce China as a strategic partner of the EU, and not a potential threat. This label highlights the EU's ambition for constructive engagement with China and comports with its objective to strengthen cooperation on global security issues. This strategy has led scholars such as Shambaugh to state that the EU and China represent an "emerging axis in world affairs." ${ }^{\circ 0}$ In sum, within these two documents, the European Union is consistently highlighting its importance as a global security actor and norm-promoter with respect to Chinese partnerships. Clearly, the EU is aiming to influence China to follow its international security model, particularly vis-à-vis its core norm of multilateralism. The 2003 documents thus show a strong normative emphasis directed at transforming Chinese foreign policy and fostering inter-party cooperation.

\section{Documents}

In 2016, the European Union promulgated the EU Global Strategy (EUGS), while the European Commission released a policy paper, "Elements for a New EU Strategy on China." Both documents indicate a clear shift in the EU's approach towards international affairs, and in

[60] David Shambaugh, "China and Europe: The Emerging Axis," Current History 103.674 (2004): 243-248, https://www.jstor.org/stable/45317958 particular, its relationship with China. The EUGS was introduced to redefine the CFSP in response to a changing global threat environment. In terms of threat perception, it identifies five priorities for the CFSP: (1) the Union's internal security; (2) the Eastern and Southern neighborhood; (3) the development of an integrated approach to conflict and crises; (4) cooperative regional orders; (5) strengthening its multilateral, rule-based system of global governance. ${ }^{61}$ While both documents still highlight international threats, the EU's focus has largely shifted towards Europe and its neighboring powers, rather than more distant regions of the world. As a report commissioned by the European Union states, "we will take responsibility foremost in Europe and its surrounding regions, while pursuing targeted engagement further afield." ${ }^{62}$ In regard to policy response, the EUGS and the EU's new strategy towards China introduced the concept of "principled pragmatism" as a guide for any future external actions; essentially, that foreign policy "should be principled, practical and pragmatic." ${ }^{\prime 3}$ This can be interpreted as a rejection of idealism and a consolidation towards realist policy-both when dealing with China and the international community more broadly. However, multilateralism, with the UN at its core, remains the EU's key principle when addressing global security threats.

In the "New EU Strategy on China," an entire section is dedicated to the joint promotion of effective multilateralism, and the need for the EU to seek a broader foreign policy agenda based on encouraging China's constructive and active participation in providing security as a global public good. In line with its support for a multilateral approach, it also calls for co-responsibility and cooperation through partnerships and international organizations. Similar to the EU's 2003 documents on China and international security, sovereignty and interventionism are not dis-

[61] "Joint Communication to the European Parliament and the Council: Elements for a New EU Strategy on China," report, European Commission (2016), https://eur-lex.europa.eu/legal-content/en/ALL/?uri=celex:52016JC0030

[62] "Shared Vision, Common Action: A Stronger Europe," report, European Union (2016), https://op.europa.eu/en/publication-detail/-/publication/3eaae2cf-9ac5-11e6-868c-01aa75ed71al

[63] Ibid. 
cussed in great detail. While respect for sovereignty, independence, and the territorial integrity of all states remains a key principle of $\mathrm{EU}$ foreign policy, the 2016 documents also stress the importance of acting as a responsible global stakeholder. In sum, the EUGS demonstrates a higher level of self-interest on the part of the EU, as it is directed towards providing security for the European continent, rather than external projection of its core norms. The 2016 strategy stresses the importance of reciprocity in EU-China relations, but does not abandon normative aspirations towards China. Although the EU is still devoted to promoting its norms while seeking to "marry [its] experience with China’s resources," this normative promotion is tempered with pragmatism and caution. ${ }^{64}$

\section{Documents}

The final documents that will be analyzed are the EU's recently published strategy document on China, "EU-China: A Strategic Outlook," and the EU's "2019 Report on the Implementation of the EUGS." In terms of threat perception, it is notable that the EU sees China's promotion of "alternative models of governance" as a potential threat. Domestic and regional focus has strengthened, while the growing complexity and interdependence of security issues is still emphasized. As the Report on the EUGS notes, "global trends have not only been confirmed; they have deepened and have become more intertwined." complexity is linked to the shift from a unipolar world to an increasingly fragmented multipolar distribution of power, which the report characterizes as not having led "to more cooperation, but rather to growing uncertainty and rivalry."66 Furthermore, the report highlights how multipolar contestation has not only intensified economic and trade tensions, but also cross-advocacy of different modes of global governance and intervention in regional conflicts and rivalries. In terms of policy

[64] "Joint Communication to the European Parliament and The Council," 11.

[65] "The European Union's Global Strategy Three Years on, Looking Forward," report, European Union (2019): 8, https://eeas.europa.eu/sites/default/files/eu_global_strategy_2019.pdf

[66] Ibid., 8. response, both documents re-emphasize the importance of multilateralism to counter global fragmentation. The "Report on the Implementation of the EUGS" highlights the EU's role in supporting and reforming multilateral governance in recent years through increased financial contributions to the UN and preserving the nuclear deal with Iran. The EU identifies multilateral global governance as a strategic priority, and sees it as its responsibility to sustain, defend and promote. It even self-identifies as "the go-to power" and "point of reference" when it comes to multilateralism, asserting that it is "the most advanced multilateral project in history." ${ }^{\prime \prime}$ Sovereignty and interventionism-related statements are completely absent from both documents, which could indicate that the EU has either deprioritized these issues entirely, or that there is no change in EU policy. The EU's new strategy on China reframes their relationship by introducing the term systemic rival-this can be contrasted to the 2003 framing of China as a strategic partner. ${ }^{68}$ The re-labelling of their relationship illustrates the EU's increasingly pragmatic approach towards China. In line with the 2016 strategy on China, reciprocity and coordination are also emphasized. ${ }^{69}$ The EU's less optimistic approach towards China and the label of systemic rival, however, do not put an end to its engagement with China and its ambition for increased cooperation-the 2019 strategy still identifies China as a "cooperation partner with whom the EU has closely aligned objectives" in several areas. ${ }^{70}$

\section{China's Approach to International Security and the EU}

\section{3-2004 Documents}

I will now contrast the EU's approach towards China and international security with China's approach to the same. The first documents that will be analyzed are a 2003 policy paper on the EU and a 2004 white paper, "China’s National Defense in 2004." China’s 2003 policy paper on

[67] Ibid.

[68] "EU-China: A Strategic Outlook," report, European Commission (2019): 10, https://ec.europa.eu/info/publications/eu-china-strategic-outlook-commission-contribution-european-council-21-22-march-2019_en

[69] “The European Union's Global Strategy Three Years on, Looking Forward," 1. [70] Ibid. 
the EU is the first of its kind, detailing China's planned approach towards the EU in the following years. Notably, the 2003 policy paper on the EU clearly states that "neither side poses a threat to the other." ${ }^{11}$ The white paper on national defense largely introduces China's defense and militarization policy, but also contains a chapter on international security cooperation that is particularly relevant.

In terms of threat perception, the documents recognize the high volatility of international affairs, and seek to highlight the resulting growth in uncertainty, instability, and insecurity. ${ }^{72}$ China's 2004 defense strategy sees the current mix between unipolarity and multipolarity as leading to hegemonism, and views struggles for strategic interests and dominance as problematic and counterproductive. China is particularly concerned with global security threats linked to economic globalization and any resulting wage and income gaps. Interestingly, in the document, China is identified as a "developing country." This appears to be a form of strategic hedging against adverse actions by established powers, as the document continually stresses the peaceful and defensive nature of Chinese expansion and growth. In the area of military technology, the documents highlight more specific threats, such as terrorism, the safeguarding of international arms control, disarmament, non-proliferation regimes, and the rise of both local and regional armed conflicts. ${ }^{73}$ Finally, the defense strategy draws a regional focus on the Asia-Pacific region, and notes several non-traditional security issues, particularly those linked to the environment.

Although multilateralism is not specifically mentioned in either document, the concept implicitly undergirds the premises of both documents, as they not only emphasize a preference for increased coopera-

[71] “China's EU Policy Paper," website, Ministry of Foreign Affairs of the People's Republic of China, October 13, 2003, https://www.fmprc.gov.cn/mfa_eng/topics_665678/ ceupp_665916/t27708.shtml

[72] See "China's National Defense in 2004," website, Information Office of the State Council, December 2004, http://en.people.cn/whitepaper/defense2004/defense2004. html

[73] Ibid. tion in response to global threats, but do so in the context of multilateral institutions. ${ }^{74}$ For instance, in a chapter on international security, China's defense paper states that "the Chinese government pays great attention to, and actively participates in, international security cooperation and advocates the development of international security cooperation based on the UN Charter." ${ }^{75}$ This chapter explicitly details Chinese security cooperation with Russia, the United States, and neighboring countries in the Asia-Pacific. There is, however, no specific reference to EU-China cooperation. However, the 2003 policy paper does indicate a need for increased cooperation with the $\mathrm{EU}$ on a wide range of security-related issues, and also calls for stronger EU-China cooperation at the UN. ${ }^{76}$ Finally, in contrast to the EU's 2003 policy documents, sovereignty and non-interventionism play a major role in Chinese foreign policy vis-àvis the Five Principles of Peaceful Coexistence: (1) mutual respect for each other's territorial integrity and sovereignty, (2) mutual non-aggression, (3) mutual non-interference in each other's internal affairs, (4) equality and mutual benefit, and (5) peaceful co-existence. ${ }^{77}$ As such, we can see that while China is still primarily focused on national policy, it is beginning to assume greater responsibility as a regional and international power. ${ }^{7}$ In terms of EU-China relations, China's self-perception as a developing country is complemented by its recognition of the EU's role as a key global actor that "will play an increasingly important role in both regional and international affairs."79 The 2003 Chinese strategy on the EU thus outlines prospects for closer consultation and broader cooperation with the $\mathrm{EU}$ on security issues.

\section{4-2015 Documents}

Next, I will analyze a key policy paper published in 2014, "China's 2014 Policy Paper on the EU: Deepen the China-EU Comprehensive Strategic Partnership for Mutual Benefit and Win-Win Cooperation," and

[74] Ibid.

[75] Ibid.

[76] “China’s EU Policy Paper (2003)."

[77] Ibid.

[78] "China's National Defense in 2004."

[79] "China's EU Policy Paper (2003)." 
President Xi Jinping's 2015 speech at the General Debate of the 7oth Session of the UN General Assembly. In terms of threat perception, both documents illustrate a deepening of the trend towards multipolarity first identified in the earlier documents. In other words, they articulate less of a focus on national and regional security, and more of a focus on global issues. ${ }^{80}$ No specific threats to security are mentioned, but the documents recognize the importance of addressing non-traditional security threats-specifically, the need for sustainable development. ${ }^{{ }^{81}}$ In terms of policy response, there is a clear focus on enhanced cooperation through increased contributions to ensure the "peace and prosperity of the world," as well as an on-going commitment to uphold the authority of the UN and support its aim for world peace. ${ }^{82}$ In his speech, Xi Jinping highlights China's commitment to multilateralism; its rejection of unilateralism; and the importance of dialogue, consultation, and partnerships in international governance. ${ }^{8_{3}}$ Moreover, he emphasizes the principle of sovereign and territorial integrity laid out in the UN Charter, and adds that the concept of sovereignty should also extend to social systems and the development paths of countries. Xi thus emphasizes China's promotion of alternative models of governance, as well as its self-identification as a developing country. ${ }^{84}$

On the other hand, China's 2014 policy paper on the EU outlines a more pragmatic way to strengthen the relationship. It devotes a whole section to "expanding defense and security cooperation," and calls for an expan-

[80] "China's Policy Paper on the EU: Deepen the China-EU Comprehensive Strategic Partnership for Mutual Benefit and Win-Win Cooperation," website, Ministry of Foreign Affairs of the People's Republic of China, April 2, 2014, https://www.fmprc.gov.cn/ mfa_eng/wjdt_665385/wjzcs/tl143406.shtml; Xi Jinping, “Working Together to Forge a New Partnership of Win-Win Cooperation and Create a Community of Shared Future for Mankind," speech, General Debate of the 70th Session of the UN General Assembly (New York, NY), United Nations, September 28, 2015, https://www.fmprc.gov.cn/ mfa_eng/topics_665678/xjpdmgjxgsfwbcxlhgcl70znxlfh/t1305051.shtml

[81] Xi, "Working Together to Forge a New Partnership of Win-Win Cooperation and Create a Community of Shared Future for Mankind."

[82] "China's Policy Paper on the EU (2014)."

[83] Xi, "Working Together to Forge a New Partnership of Win-Win Cooperation."

[84] Ibid. sion in "the area and scope of practical cooperation between the two sides." ${ }^{5}$

In these two documents, we can see that Chinese self-confidence is growing, despite its purposeful identification as a rising power. By promoting "a new type of international relations" that is based on the principles of "equality, mutual trust, inclusiveness, mutual learning, and win-win cooperation," China is stepping into a new role as norm-maker and norm-promoter. ${ }^{86}$ Accordingly, as "the world's most representative emerging economy," China seeks to create a more equal and balanced relationship with the EU-which it terms the world's most representative "group of developed countries." ${ }^{\prime 7}$ The document thus recognizes the EU as a crucial strategic partner in the pursuit of both peaceful development and a multipolar world, calling for a "deepening of the China-EU Comprehensive Strategic Partnership for Mutual Benefit and Win-Win Cooperation." ${ }^{8}$

\section{8-2019 Documents}

The final Chinese documents dealing with the EU and international security that will be analyzed are the 2018 policy paper, "China's Policy $\mathrm{Pa}$ per on the European Union," and a 2019 white paper, "China's National Defense in the New Era." In terms of threat perception, these documents note a rise of unilateralism linked to international strategic competition, protectionism, and de-globalization. They also mention specific global security threats, including international arms control, terrorism and extremism, and new non-traditional security threats related to outer space, cyber security, bio-security, and piracy. ${ }^{89}$ Not only does the 2019 white paper make reference to global issues (such as the Iranian nuclear deal and the Syrian Civil War), it also notes important regional and

[85] "China's Policy Paper on the EU (2014)."

[86] Xi, "Working Together to Forge a New Partnership of Win-Win Cooperation."

[87] "China's Policy Paper on the EU (2014)."

[88] Ibid.

[89] Ibid.; "China's National Defense in the New Era," white paper, State Council Information Office of the People's Republic of China, 1st ed. (July 2019), http://www.xinhuanet.com/english/2019-07/24/c_138253389.htm 
internal challenges, including separatist movements in Taiwan and territorial disputes in the South China Sea. In terms of policy response, it is notable that China has continued to stress its contribution to global governance through the United Nations. In other words, multilateralism is a key norm of Chinese foreign policy-one that is repeatedly emphasized in both documents. In concert, the EU policy paper contains an extensive section detailing ambitions for further cooperation in the fields of politics, security, and defense. Importantly, compared to previous policy papers, this section comes before the sections on trade, development, and social cooperation..$^{\circ}$ Sovereignty and non-interference are not mentioned extensively, besides a restatement of Chinese commitment to the Five Principles of Peaceful Coexistence and opposition "to interference in the international affairs of others, abuse of the weak by the strong, and any attempt to impose one's will on other." ${ }^{\prime 1}$ Finally, both documents follow in the footsteps of the 2014/2015 strategies, and further emphasize China's promotion of a "New-Model" security partnership featuring equality, mutual trust, and "win-win cooperation."

Through these documents, we can see that China is asserting its normative leadership as a rising power, and that it's determined to be perceived as such by its partners-and particularly, the EU. This is particularly apparent in the 2018 policy paper, which demands the EU to "explicitly oppose Taiwan independence" and to honor "its commitment to respect China's sovereignty and territorial integrity."92 It even goes as far as to state that the EU needs to respect China's core interests in order to assure "the long-term stability and growth of China-EU relations." ${ }^{33}$ While this depicts a hardening stance towards the EU, more of the paper seeks to highlight the progress made thus far, as well as outlining how to further strengthen Chinese-European relations, particularly in the security domain.

[90] "China's Policy Paper on the European Union," website, Ministry of Foreign Affairs of the People's Republic of China, December 18, 2018, https://www.fmprc.gov.cn/ mfa_eng/wjdt_665385/2649_665393/t1622890.shtml

[91] "China’s National Defense in the New Era."

[92] "China's Policy Paper on the European Union (2018)."

[93] Ibid.

\section{Measuring the Extent of Normative Convergence}

Thus far, I have noted the discursive trends and differences between a selection of official policy papers in the EU and China from 2003 to the present. Now, I will thematically compare the two sets of documents across time to identify the extent of normative convergence between the two powers. The first time period, 2003/2004, shows a rather low level of convergence between the powers. There is a marginal convergence in the realm of threat perception, as both actors highlight multipolarity, the changing nature and growing interdependency of security threats, and some common threats, such as terrorism and WMD proliferation. However, the Chinese documents emphasize a greater national and regional focus, while the EU's security strategy is strongly focused on comprehensive external threats. Similar findings exist in the realm of policy response. Although both China and the EU stress the need for increased cooperation to address global security threats, while advocating for a greater role for the UN in global governance, there are significant differences with respect to their relative understandings of key concepts, such as multilateralism and sovereignty. First of all, the EU documents outline an ambitious and detailed approach for dealing with new security threats, whereas the Chinese documents largely gloss over similar practical considerations. Second, while the concepts of national sovereignty and non-interference saturate the Chinese policy documents, they are minimized in the European documents-in fact, the EU documents repeatedly advocate for an expansion of the responsibility to protect doctrine. Finally, while the EU documents emphasize and externalize multilateralism, the Chinese documents implicitly call for increased security cooperation, but do not explicitly refer to multilateralism or multilateral action. Therefore, while there is an observable convergence on security norms between the EU and China in 2003 and 2004, it was minimal at best.

However, a decade later, in 2014-2016, similar documents evince significant changes to both European and Chinese approaches to global security, and a higher level of normative convergence between the two actors. Threat perception converged, as both the EU and China began 
to increasingly highlight and respond to similar non-traditional security threats. Moreover, with respect to extra-national influence, China and the EU met halfway (so to speak), as the EU shifted focus to domestic and regional security, while China expanded its global ambitions. In the realm of policy response, both the EU and China adopted a more pragmatic and flexible approach to each other-this is particularly apparent when examining China's more explicit support for multilateralism and lessened focus on non-interference. The documents from 2018 and 2019 show similar trends, as discourses on threat perception and policy responses have continued to converge. Although my analysis of the final and most recent period has depicted a shift towards a more competitive relationship, threat perception and policy response has mostly stayed convergent.

Accordingly, I have identified a gradual normative rapprochement between the EU and China on global threat perception and security norms since 2003. Overall, China remains committed to the importance of multilateralism, and has adopted a more flexible understanding of sovereignty and non-interference, bringing it closer to the EU's approach to international security. Similarly, I have found no significant changes in the EU's approach towards sovereignty and multilateralism, but identified alterations in its general foreign policy strategy such as the downgrading of transformative normative aspirations in favor of a more pragmatic and flexible approach to global security and Chinese-European cooperation.

\section{Case Study: Normative Convergence and Peacekeeping in the Democratic Republic of Congo (DRC)}

Next, I will test the previously identified normative convergence within a specific security domain: peacekeeping missions in the Democratic Republic of Congo (DRC). We will study both the EU's and China's approach to peacekeeping and apply our analytical framework to assess if normative convergence can serve as evidence of actual cooperation.

The European Union's Approach to Peacekeeping in the DRC

Since the early 2000s, the European Union has developed into an in- creasingly active crisis management actor. Following the guidance of the ESS, in 2003, it launched its first autonomous military mission abroad, Operation Artemis, formerly known as EUFOR DRC. ${ }^{94}$ Artemis was primarily launched in response to a call by the UN Secretary-General for a temporary international support force to aid the UN MONUC (MONUSCO) mission, which had been active in DRC since 1999. ${ }^{95}$ Since 2003, the EU has remained active in the DRC, with several active missions, including EUFOR RD Congo, EUPOL Kinshasa, EUSEC RD Congo, and EUPOL RD Congo..$^{96}$ In terms of threat perception, the EU has identified regional conflicts and state failure as key global security threats in several of its documents, and particularly, the Great Lakes regional conflict in the DRC. ${ }^{97}$ To the EU, regional conflicts-especially in Africa and other regions adjacent to the European continent-do not merely represent a threat to regional stability, but also threaten Europe itself due to global security interdependence. A conflict in Africa could, for example, lead to extremism and terrorism, organized crime, increased demand for weapons of mass destruction, and illegal migration to the EU. ${ }^{98}$ Repeated attacks on the UN's mission in the DRC over the last few years have been recognized as a sign of ongoing instability, continued threat, and an amplified need for further action. ${ }^{99}$ Therefore, the EU

[94] "Council Decision 2003/432/CFSP on the launching of the European Union military operation in the Democratic Republic of Congo," document, European Council, No. 32003D0432 (2003), https://eur-lex.europa.eu/legal-content/EN/TXT/?uri=CELEX\%3A32003D0432

[95] MONUSC was renamed to MONUSCO in May 2010. UN Security Council Resolution 1484, "The Situation Concerning the Democratic Public of the Congo," S/ RES/1484 (May 2003), http://unscr.com/en/resolutions/1484; UN Security Council Resolution 1925, "The Situation Concerning the Democratic Republic of the Congo," S/ RES/1925 (May 2010), http://unscr.com/en/resolutions/1925

[96] UN Security Council Resolution 1671, “The Situation Concerning the Democratic Republic of the Congo," S/RES/1671 (April 2006). http://unscr.com/en/resolutions/1671; "Military and Civilian Missions and Operations," European External Action Service, March 5, 2019, https://eeas.europa.eu/topics/military-and-civilian-missions-and-operations/430/military-and-civilian-missions-and-operations_en

[97] "Shared Vision, Common Action."

[98] "A Secure Europe in a Better World."

[99] "Statement by the Spokesperson Regarding the Attack on MONUSCO in the Democratic Republic of the Congo," European External Action Service, May 6, 2015, 
perceives its investment in African peace and economic development as an investment in its own security and prosperity. ${ }^{100}$

Having discussed the EU's motivations for maintaining peacekeeping efforts in the DRC, I will now analyze the security norms governing its approach towards the issue at hand, with a focus on multilateralism and sovereignty. First, participation in peacekeeping missions reflects the EU's support for effective multilateralism through the United Nations. This strong commitment is illustrated through by the fact that EU operations in the DRC were initially launched in support of the UN, explicitly sought to operate in accordance with UN objectives and values, and were conducted solely under the UNSC mandate. ${ }^{101}$ One could argue that the existence of other autonomous EU missions are, to some extent, competing with UN missions and therefore do not necessarily represent cases of effective UN-centered multilateralism on the ground. However, this argument is severely weakened by the EU's recurring statements calling for continued cooperation with the UN in the peacekeeping domain-even as the two powers operate different missions. ${ }^{102}$ High Representative Federica Mogherini, for instance, argued in 2019 that the “"European way' towards peace and security is identical to the 'UN way' towards peace and security," making the EU and UN natural partners

https://eeas.europa.eu/election-observation-missions/eom-zambia-2016/3381/statement-by-the-spokesperson-regarding-the-deadly-attack-against-monusco_en; "Statement by the Spokesperson on the Situation in the Democratic Republic of the Congo," European External Action Service, January 23, 2018, https://eeas.europa.eu/delegations/ australia/38731/statement-spokesperson-situation-democratic-republic-congo_en

[100] "Shared Vision, Common Action."

[101] Ibid.; "A Secure Europe in a Better World"; Catherine Ashton, "Address at the United Nations Security Council," speech, United Nations Security Council (New York, NY), February 8, 2011, https://ec.europa.eu/commission/presscorner/detail/en/ SPEECH_11_77; Federica Mogherini, "Address at the United Nations Security Council," speech, United Nations Security Council (New York, NY), March 12, 2019, https:// eeas.europa.eu/headquarters/headquarters-homepage/59506/speech-high-representativevice-president-federica-mogherini-united-nations\%E2\%80\%99-security-council_en

[102] “Joint Declaration on UN-EU Cooperation in Crisis Management," United Nations, September 24, 2003, https://ec.europa.eu/commission/presscorner/detail/en/ PRES_03_266 and collaborators. ${ }^{103}$ She particularly highlights EU-UN cooperation on conflict resolution in Africa, as well as the recent launch of a trilateral security effort between the EU, UN and African Union (AU). ${ }^{104}$

In terms of sovereignty, my analysis shows that the EU supports a form of pooled or shared sovereignty, as displayed by its support for multilateral intervention in this regional conflict. While the EU declared that the peace process in the DRC is "above all, the responsibility of the Congolese people," it is also a key supporter of AU security operations, as well as the application of international law to address regional security issues in the DRC. More specifically, the EU has supported the AU in its role as a regional security actor through several channels, including the implementation of the African Peace Facility, a financial instrument supporting AU initiatives, and operational support for the African Standby Force. ${ }^{105}$

\section{China's Approach to Peacekeeping in the DRC}

In stark contrast to its initial opposition to international peacekeeping when it first joined the United Nations in 1971, the PRC has begun to emerge as a key contributor to UN peacekeeping operations within the last decade. Keeping pace with its increased funding contributions, Chinese personnel contributions have increased from 52 troops in 2000 to 1,868 in 2013, making it one of the main contributors of both peacekeeping troops and funds. ${ }^{106}$ In terms of threat perception, intervention in regional conflicts and the need to participate in UN peacekeeping operations were emphasized early on in China's 2004 defense strategy. Although regional conflicts in Africa do not affect China directly, as they

[103] Mogherini, "Address at the United Nations Security Council."

[104] Ibid.; Catherine Ashton, "Declaration by the High Representative, Catherine Ashton, on Behalf of the European Union on the Situation in the Eastern Democratic Republic of the Congo," European Union, July 10, 2012, https://www.consilium.europa.eu/ uedocs/cms_Data/docs/pressdata/EN/foraff/131682.pdf

[105] “3rd Africa EU-Summit 29/30 November, Tripoli," memorandum, European Union (November 2010), https://ec.europa.eu/commission/presscorner/detail/en/ MEMO_10_604

[106] See Huotari, Gaspers, and Eder et al., "China’s Emergence as a Global Security Actor: Strategies for Europe." 
do not occur in its immediate neighborhood, they still represent an economic threat due to the significant levels of Chinese investment in the region. As the Center for Strategic and International Studies notes, "China has significant investments in the DRC, including an 8o percent stake in one of the world's largest copper and cobalt mines."107 Therefore, regional stability is crucial for Chinese economic interests, and explains China's interest and involvement in the MONUSCO mission. ${ }^{108}$ China has condemned recent attacks on MONUSCO personnel and facilities, arguing that they reflect ongoing instability and the need for an continued international response.

China also has a normative interest in maintaining peacekeeping forces in the region. As previously mentioned, the concept of multilateralism has gradually gained importance in Chinese foreign policy. As such, Chinese commitment to peacekeeping missions allows China to publicly demonstrate its commitment to international institutions and multilateral action. For instance, at the UN General Assembly in 2015, Xi Jinping announced several measures to further support UN peacekeeping, including additional troops, the creation of a standby police force, training sessions at new Chinese Peacekeeping Military Training Centers, as well as budgetary support for the AU to build an African Standby Force and an African Capacity for Immediate Response to Crisis. ${ }^{109}$ China has also established an annual China-Africa Defense and Security Forum, and has sought to train African security forces. ${ }^{110}$ Counterintuitively, participation in peacekeeping missions also demonstrates Chinese commitment to the principles of sovereignty and non-interference. Respect for sovereign equality and the need for the host country's

[107] "Is China Contributing to the United Nations' Mission?" website, CSIS ChinaPower Project, https://chinapower.csis.org/china-un-mission/

[108] John Pomfret, "China Sending Troops as Congo Peacekeepers," Washington Post, February 12, 2003, https://www.washingtonpost.com/archive/politics/2003/02/12/china-sending-troops-as-congo-peacekeepers/4690a140-75e8-4b01-ab90-10ceeb0c3e48/

[109] Xi, "Working Together to Forge a New Partnership of Win-Win Cooperation and Create a Community of Shared Future for Mankind."

[110] "China's Second Africa Policy Paper," China Daily, December 12, 2015, https:// www.chinadaily.com.cn/world/XiattendsParisclimateconference/2015-12/05/content_22632874.htm consent is stressed in official Chinese discourse-in the DRC, Chinese participation in MONUSCO can be explained by the fact that the Congolese government had willingly agreed to the mission. Of course, it could be argued that China has adapted to the prevalent liberal mode of peacekeeping - and to some extent, has internalized existing approaches to sovereignty and interference. On the other hand, we can also see shifts in the UN's approach to peacekeeping that align more with the Chinese model of sovereignty, equality, and economic development. This can be observed in the UN's Brahimi Report, which symbolized a shift from a traditional peacekeeping approach towards more "robust peacekeeping." ${ }^{111}$ This shift was further intensified by the Declaration of Action for Peace, which reaffirmed key peacekeeping principles, including the "consent of the parties, impartiality, and non-use of force, except in self-defense and defense of the mandate."

The Extent of Normative Convergence Within the Peacekeeping Domain

After examining the European Union's and China's respective approaches towards peacekeeping operations in the DRC, we can conclude that our analysis of normative convergence is solid. In terms of threat perception, we have identified some level of convergence-both actors clearly identify regional conflict in the DRC as a security threat. Moreover, both have recently re-emphasized the need to address instability in the DRC following attacks on UN MONUSCO peacekeepers. However, there is some practical divergence between the two actors on the nature of the threat posed by regional instability in the DRC. While the EU is concerned by the potential spill-over effects of instability, China is mainly concerned with threats to its economic interests in the region. With regard to security norms, we have found significant levels of normative convergence between the EU and China-particularly in

[111] "Report of the Panel on United Nations Peace Operations," report, United Nations, No. A/55/305-S/2000/809 (2000), https://www.un.org/ruleoflaw/files/brahimi\%20report\%20peacekeeping.pdf

[112] “Action for Peacekeeping," website, United Nations Peacekeeping, https://peacekeeping.un.org/en/action-for-peacekeeping-a4p 
relation to multilateralism and international intervention. Both powers have strongly advocated for multilateral solutions to regional conflicts, highlighting the importance of regional and international organizations alike.

Some differences can be seen in the two powers' respective treatment of sovereignty-while China has traditionally taken a strict stance on sovereign equality and non-interference, the EU has largely advocated for a concept of shared sovereignty. However, my analysis has demonstrated that China's stance on sovereignty has actually evolved towards a more flexible understanding that has facilitated its participation in peacekeeping missions, indicating a certain internalization of and adaptation to existing security norms. Furthermore, while China's stance on sovereignty has to some extent converged with the existing system, it has also transformed said system by shifting the UN's traditional peacekeeping approach towards a more "robust" and practical approach to peacekeeping missions. We can therefore conclude that our analysis of both threat perception and policy responses in the peacekeeping domain support a moderate level of normative convergence between China and the European Union.

\section{Conclusion}

International security cooperation has only grown in importance with the emergence of new security threats and rising national interdependence. In our globalized world, conflict in one country may severely affect not only the stability of neighboring states, but of entire regions and distant states. In recent years, both China and the European Union have gradually increased their engagement in global security, and have emerged as major players in international affairs. While their relationship has often been portrayed in a negative light, I argue that there has been a recent shift of focus towards cooperation and rapprochement. My macro analysis of key EU and Chinese documents has demonstrated a moderate level of discursive rapprochement between the EU and China since 2003. This is particularly due to normative convergence on threat perception and multilateralism, as well as growing flexibility and pragmatism on both sides. Specifically, I have found that China and the
EU share similar perceptions of security threats, both traditional and non-traditional, and that advocacy and support for multilateralism through the UN and other multilateral organizations stand at the center of both powers' approaches to international security. Finally, China, in particular, has become more flexible and less constrained in its understanding of sovereignty and non-interference.

The case study analysis of peacekeeping in the DRC further confirmed my findings in the macro analysis. I note, however, that there is yet insufficient evidence of practical cooperation in the DRC that has resulted from this normative convergence. Further research on practical cooperation between the two actors in the peacekeeping domain should be conducted-perhaps through interviews with Chinese and EU military officials involved in peacekeeping operations within the DRC. Ultimately, this research contributes to a wider debate in the academic literature on EU-China relations, as well as policy circles concerned with the rise of China as a global actor. My findings of increased normative convergence strengthens the argument that a rapprochement exists between the EU and China. This finding is critical, as it not only provides a roadmap for predicting Chinese and European cooperation in the future, but also indicates that-contrary to common belief-competition between rising powers is not inexorable. Further research could attempt to measure normative convergence between other actors, such as Russia and China, or the United States and the EU. The particular security domain of peacekeeping is also of interest to researchers looking to identify normative rapprochement or divergence, as many emerging powers, such as India and Pakistan, have begun to increase contributions towards UN peacekeeping missions. The impact of pragmatism and flexibility on cooperation between global actors could also be an interesting starting point for further research.

\section{REFERENCES}

“3rd Africa EU-Summit 29/30 November, Tripoli." Memorandum. European Union. November 2010. https://ec.europa.eu/commission/presscorner/detail/en/MEMO_10_604

"A Maturing Partnership-Shared Interests and Challenges in EU-China Relations." Pol- 
icy paper. European Commission. 2003. https://eur-lex.europa.eu/LexUriServ/LexUriServ.do?uri=COM:2003:0533:FIN:EN:PDF

"A Secure Europe in a Better World." Document. Council of the European Union. December 2003. https://data.consilium.europa.eu/doc/document/ST-15895-2003-INIT/ en/pdf

"Action for Peacekeeping." Website. United Nations Peacekeeping. https://peacekeeping. un.org/en/action-for-peacekeeping-a4p

Ai Weining and Song Weiqing. "China and the European Unions' Participation in Conflict Resolution: Norm Dynamics, Convergence and Divergence in Foreign Policy." Journal of Contemporary China 28.116 (2019): 277-292. https://doi.org/10.1080/106705 64.2018.1511397

Alden, Chris, and Daniel Large. "On Becoming a Norms Maker: Chinese Foreign Policy, Norms Evaluation and the Challenges of Security in Africa." China Quarterly 221 (2015): 123-142. https://doi.org/10.1017/S0305741015000028

Allison, Graham. Destined for War: Can America and China Escape the Thucydides Trap? Boston, MA: Houghton Mifflin, 2017

Ashton, Catherine. "Address at the United Nations Security Council." Speech. United Nations Security Council, New York, NY. February 8, 2011. https://ec.europa.eu/commission/presscorner/detail/en/SPEECH_11_77

- - . "Declaration by the High Representative, Catherine Ashton, on Behalf of the European Union on the Situation in the Eastern Democratic Republic of the Congo." European Union. July 10, 2012. https://www.consilium.europa.eu/uedocs/cms_Data/ docs/pressdata/EN/foraff/131682.pdf

Biscop, Sven, and Liselotte Odgaard. "The EU and China: Partners in Effective Multilateralism." In The International Politics of EU-China Relations, edited by David Kerr and Liu Fei. Oxford University Press, 2006. https://doi.org/10.5871/ bacad/9780197264089.001.0001

"China's EU Policy Paper." Ministry of Foreign Affairs of the People's Republic of China. October 13, 2003. https://www.fmprc.gov.cn/mfa_eng/topics_665678/ceupp_665916/ t27708.shtml

"China's National Defense in 2004." Information Office of the State Council. December 2004. http://en.people.cn/whitepaper/defense2004/defense2004.html

"China's National Defense in the New Era." White paper. State Council Information Of fice of the People's Republic of China. 1st Edition. July 2019. http://www.xinhuanet.com/ english/2019-07/24/c_138253389.htm
"China's Policy Paper on the EU: Deepen the China-EU Comprehensive Strategic Partnership for Mutual Benefit and Win-Win Cooperation." Ministry of Foreign Affairs of the People's Republic of China. April 2, 2014. https://www.fmprc.gov.cn/mfa_eng/ wjdt 665385/wjzcs/t1143406.shtml

"China's Policy Paper on the European Union." Ministry of Foreign Affairs of the People's Republic of China. December 18, 2018. https://www.fmprc.gov.cn/mfa_eng/ wjdt_665385/2649_665393/t1622890.shtml

“China’s Second Africa Policy Paper." China Daily. December 12, 2015. https://www.chinadaily.com.cn/world/XiattendsParisclimateconference/2015-12/05/content_22632874. htm

Christensen, Peer M., and Li Xing. "China's Self-Perception of Its Security Situation The Nexus of the Internalities and Externalities." Journal of China and International Relations 1.1 (2013): 26-45. https://doi.org/10.5278/ojs.jcir.vli1.215

Chu Shulong. "China's Perception and Policy About North Korea." American Foreign Policy Interests 37.5-6 (2015): 273-278. https://doi.org/10.1080/10803920.2015.1162065

"Council Decision 2003/432/CFSP on the launching of the European Union military operation in the Democratic Republic of Congo." Document. European Council. No. 32003D0432. 2003. https://eur-lex.europa.eu/legal-content/EN/TXT/?uri=CELEX$\% 3 \mathrm{~A} 32003 \mathrm{D} 0432$

Damro, Chad. "Market Power Europe." Journal of European Public Policy 19.5 (2012): 682-699. https://doi.org/10.1080/13501763.2011.646779

Dossi, Simone. "The EU, China and Nontraditional Security: Prospects for Cooperation in the Mediterranean Region." Mediterranean Quarterly 26.1 (2015): 77-96. https:// doi.org/10.1215/10474552-2872988

Drezner, Daniel W. "Globalization and Policy Convergence." International Studies Review 3.1 (2011): 53-78. https://doi.org/10.1111/1521-9488.00225

Duchêne, Francois. "Europe's Role in the World." In Europe Tomorrow, 32-47, ed. Richard Mayne. Glasgow, GBR: Fontana, 1972.

"EU-China: A Strategic Outlook." Report. European Commission. March 2019. https:// ec.europa.eu/info/publications/eu-china-strategic-outlook-commission-contribution-european-council-21-22-march-2019_en

Finamore, Salvatore. "Normative Differences in Chinese and European Discourses on Global Security: Obstacles and Opportunities for Cooperation." Chinese Political Science Review 2 (2017): 159-178. https://doi.org/10.1007/s41111-017-0049-z

Geeraerts, Gustaaf. “The EU-China Partnership: Balancing Between Divergence and 
Convergence." Asia Europe Journal 17.3 (2019): 281-294. https://doi.org/10.1007/s10308019-00554-2

Gottwald, Jörn-Carsten, and Niall Duggan. "Hesitant Adaptation: China’s New Role in Global Policies." In Role Theory in International Relations, edited by Sebastian Harnisch, Cornelia Frank, and Hanns W. Maull. London, GBR: Routledge, 2011.

Halperin, Sandra, and Oliver Heath. Political Research: Methods and Practical Skills. New York, NY: Oxford University Press, 2017.

Hirono, Miwa, and Marc Lanteigne. "Introduction: China and UN Peacekeeping." International Peacekeeping 18.3 (2011): 243-256. https://doi.org/10.1080/13533312.2011.563070

Huotari, Mikko, Jan Gaspers, Thomas Eder, Helena Legarda, and Sabine Mokry. "China's Emergence as a Global Security Actor: Strategies for Europe." Report. Mercator Institute for China Studies. In MERICS Papers on China 4 (June 2017): 4-133. https://merics.org/en/report/chinas-emergence-global-security-actor

"Is China Contributing to the United Nations' Mission?" Website. CSIS ChinaPower Project. https://chinapower.csis.org/china-un-mission/

Jing Men and Ramon P. Pardo. "Convergence and Divergence Between the EU and China." Asia Europe Journal 12.1-2 (2014): 1-3. https://doi.org/10.1007/s10308-014-0377-7

"Joint Communication to the European Parliament and the Council: Elements for a New EU Strategy on China." Report. European Commission. June 2016. https://eur-lex. europa.eu/legal-content/en/ALL/?uri=celex:52016JC0030

“Joint Declaration on UN-EU Cooperation in Crisis Management." United Nations. September 24, 2003. https://ec.europa.eu/commission/presscorner/detail/en/ PRES_03_266

Kaldor, Mary, Mary Martin, and Sabine Selchow. "Human Security: A New Strategic Narrative for Europe." International Affairs 83.2 (2007): 273-288. https://doi.org/10.1111/ j.1468-2346.2007.00618.x

Kerr, Clark. The Future of Industrial Societies: Convergence or Continuing Diversity? Cambridge, MA: Harvard University Press, 1983. https://doi.org/10.4159/harvard. 9780674497627

Kerr, David, and Xu Yanzhuo. "Europe, China and Security Governance: Is There Evidence of Normative Convergence?" Asia Europe Journal 12 (2014): 79-93. https://doi. org/10.1007/s10308-014-0371-0

Kirchner, Emil, Thomas Christiansen, and Han Dorussen. Security Relations Between China and the European Union: From Convergence to Cooperation? Cambridge, GBR: Cambridge University Press: 2016. https://doi.org/10.1017/CBO9781316563243
Liu Guoli. "Leadership Transition and Chinese Foreign Policy." Journal of Chinese Political Science 8.1 (2003): 107, https://doi.org/10.1007/BF02876952

Liu Lei, Wu Tong, and Wan Ziqianhong. "The EU-China relationship In a New Era of Global Climate Governance." Asia Europe Journal 17.2 (2019): 243-254. https://doi. org/10.1007/s10308-018-00530-2

Lucarelli, Sonia, Luk Van Langenhove, and Jan Wouters. The EU and Multilateral Security Governance. Abingdon, GBR: Routledge, 2013. https://doi.org/10.4324/9780203095430

Maher, Richard. “The Elusive EU-China Strategic Partnership." International Affairs 92.4 (2016): 959-976. https://doi.org/10.1111/1468-2346.12659

Manners, Ian. "Normative Power Europe: A Contradiction in Terms?" Journal of Common Market Studies 40.2 (2002): 235-258. https://doi.org/10.1111/1468-5965.00353

"Military and Civilian Missions and Operations." European External Action Service. March 5, 2019. https://eeas.europa.eu/topics/military-and-civilian-missions-and-operations/430/military-and-civilian-missions-and-operations_en

Mogherini, Federica. “Address at the United Nations Security Council.” Speech. United Nations Security Council, New York, NY. March 12, 2019. https://eeas.europa.eu/headquarters/headquarters-homepage/59506/speech-high-representativevice-president-federica-mogherini-united-nations\%E2\%80\%99-security-council_en

Montesano, Francesco S. "EU-China Security Relations: Discourse vs Practice and the Role of EU Member States." International Spectator 54.2 (2019): 139-158. https://doi.org/ 10.1080/03932729.2019.1572356

Organski, Abramo F.K. World Politics. New York, NY: Alfred A. Knopf, 1958.

Palm, Trineke, and Ben Crum. "Military Operations and the EU's Identity As an International Security Actor." European Security 28.4 (2019): 513-534. https://doi.org/10.1080 /09662839.2019.1667769

Pardo, Ramon P. "EU-China Relations in Financial Governance: Cooperation, Convergence or Competition?" Asia Europe Journal 12.1-2 (2014): 63-77. https://doi.org/10.1007/ s10308-014-0372-z

Pomfret, John. "China Sending Troops as Congo Peacekeepers." Washington Post. February 12, 2003. https://www.washingtonpost.com/archive/politics/2003/02/12/chinasending-troops-as-congo-peacekeepers/4690a140-75e8-4b01-ab90-10ceeb0c3e48/

"Report of the Panel on United Nations Peace Operations." Report. United Nations. No. A/55/305-S/2000/809. 2000. https://www.un.org/ruleoflaw/files/brahimi\%20report\%20peacekeeping.pdf 
"Report on the Implementation of the European Security Strategy: Providing Security in a Changing World." Report. European Union. December 2008. https://www.consilium.europa.eu/uedocs/cms_data/docs/pressdata/en/reports/104630.pdf

Scott, David. "Environmental Issues as a 'Strategic' Key in EU-China Relations." Asia Europe Journal 7.2 (2009): 211-223. https://doi.org/10.1007/s10308-009-0227-1

Shambaugh, David. "China and Europe: The Emerging Axis." Current History 103.674 (2004): 243-248. https://doi.org/10.1525/curh.2004.103.674.243

"Shared Vision, Common Action: A Stronger Europe." Report. European Union. June 2016. https://op.europa.eu/en/publication-detail/-/publication/3eaae2cf-9ac5-11e6-868c -01aa75ed7lal

Sicurelli, Daniela. "Competing Models of Peacekeeping: The Role of the EU and China in Africa." Conference paper. Fifth Pan-European Conference on EU Politics. Porto, PRT. ECPR Standing Group on the European Union. June 23-26, 2010. http://citeseerx. ist.psu.edu/viewdoc/download?doi=10.1.1.462.9906\&rep=rep1\&type=pdf

Song Xinning. "Security and the Role of China." In The Palgrave Handbook of EU-Asia Relations, edited by Thomas Christiansen, Emil Kirchner, and Philomena Murray. London, GBR: Palgrave Macmillan, 2013.

"Statement by the Spokesperson on the Situation in the Democratic Republic of the Congo." European External Action Service. January 23, 2018. https://eeas.europa.eu/delegations/australia/38731/statement-spokesperson-situation-democratic-republic-congo_en

"Statement by the Spokesperson Regarding the Attack on MONUSCO in the Democratic Republic of the Congo." European External Action Service. May 6, 2015. https://eeas.europa.eu/election-observation-missions/eom-zambia-2016/3381/statement-by-the-spokesperson-regarding-the-deadly-attack-against-monusco_en

Stumbaum, May-Britt. "Opportunities and Limits of EU-China Security Cooperation." International Spectator 42.3 (2007): 351-370. https://doi.org/10.1080/03932720701567570

"The European Union's Global Strategy Three Years on, Looking Forward." Report. European Union. 2019. https://eeas.europa.eu/sites/default/files/eu_global_strategy_2019. pdf

UN Security Council Resolution 1484. "The Situation Concerning the Democratic Public of the Congo.” S/RES/1484. May 2003. http://unscr.com/en/resolutions/1484

UN Security Council Resolution 1671. "The Situation Concerning the Democratic Republic of the Congo." S/RES/1671. April 2006. http://unscr.com/en/resolutions/1671

UN Security Council Resolution 1925. "The Situation Concerning the Democratic Re- public of the Congo." S/RES/1925. May 2010. http://unscr.com/en/resolutions/1925

Wong, Reuben. “China's Security Thinking." Policy paper. EU-China Security Cooperation, University of Essex. Published in EUSC Policy Paper Series. 2015. https://www. essex.ac.uk/-/media/documents/research/eu-china/eusc_security_china_wong.pdf

Xi Jinping, "Working Together to Forge a New Partnership of Win-Win Cooperation and Create a Community of Shared Future for Mankind." Speech. General Debate of the 70th Session of the UN General Assembly, New York, NY. September 28, 2015. https:// www.fmprc.gov.cn/mfa_eng/topics_665678/xjpdmgjxgsfwbcxlhgcl70znxlfh/t1305051. shtml

Xu Qiyu, "Managing Uncertainties: China-EU International Security Cooperation.” Occasional paper. Institute for Security and Development Policy. Published in Asia Papers Series. September 2009. https://www.isdp.eu/content/uploads/publications/2009_ qiyu_managing-uncertainties.pdf

Zhu Liqun. "China’s Foreign Policy Debates." Chaillot Papers 121 (2010): 5-75. https:// doi.org/10.2815/19538

Zwolski, Kamil. "The EU and a Holistic Security Approach after Lisbon: Competing Norms and the Power of the Dominant Discourse." Journal of European Public Policy 19.7 (2012): 988-1005. https://doi.org/10.1080/13501763.2012.662057 